\title{
СИНТЕЗ ТА ДОСЛІДЖЕННЯ АНТИОКСИДАНТНОї АКТИВНОСТІ ДЕЯКИХ ПОХІДНИХ НА ОСНОВІ 4-ІМІНОТІАЗОЛІДИН-2-ОНУ
}

\author{
()Т. І. Чабан \\ Львівський національний медичний університет імені Данила Галицького
}

\begin{abstract}
Резюме: на основі реакцій [2+3]-циклокоденсації, тіонування та амінолізу здійснено синтез нових $\mathrm{N}^{3}$ заміщених похідних 4-іміно-тіазолідин-2-ону. Для 3-феніл-4-іміно-тіазолідин-2-ону проведено функціоналізацію за положенням $\mathrm{C}^{5}$ у реакціях альдольної конденсації та нітрозування. Скринінгові дослідження антиоксидантної активності проводили in vitro з визначенням зменшення концентрації вільного радикала. Серед тестованих речовин виявлено сполуки лише з помірною активністю.
\end{abstract}

Ключові слова: [2+3]-циклокоденсація, 3-арил-4-іміно-тіазолідин-2-они, альдольна конденсація, нітрозування, антиоксидантна активність.

Вступ. Похідні тіазолідину є відомою групою біологічно активних сполук у сучасній медичній хімії [1], яка характерна широким і різноплановим спектром біологічної активності. Серед вказаного класу речовин не без успіху вивчають антибактеріальну [2], противірусну [3], фунгіцидну [4], протизапальну [5-10], протипухлинну [1113], антидіабетичну [14], протимікробну [15] та інші види фармакологічної активності.

4-Іміно-2-тіазолідони порівняно 3 ізомерними 2-іміно похідними є маловивченими об'єктами у сучасній органічній та фармацевтичній хімії. Бе- нами за відомим методом [1] відповідні 3-арилтіазолідин-2,4-діони було введено у реакцію тіонування пентасульфідом фосфору, що дозволило одержати відповідні 3-арил-4-тіоксо-тіазолідин-2-они. Дані речовини отримано в умовах аналогічних синтезу відомого 4-тіоксо-тіазолідин-2-ону (ізороданіну) [16]. Синтетичний потенціал одержаних сполук дозволив провести взаємодію 3-арил-4-тіоксо-тіазолідонів з 25 \% водним розчином амоніаку, що привело до нових неописаних у літературі 3-арил-4-іміно-тіазолідин-2-онів:<smiles>[R]c1ccc(N2C(=O)CSC2=O)cc1</smiles><smiles>[R]c1ccc(N2C(=O)SCC2=S)cc1</smiles><smiles>NC[C@H](N)O</smiles><smiles>[R]c1ccc(N2C(=N)CSC2=O)cc1</smiles>

$$
\begin{array}{ll}
\mathbf{1} \mathbf{R}=\mathrm{C}_{6} \mathrm{H}_{5} & \mathbf{3} \mathbf{R}=4-\mathrm{Cl}-\mathrm{C}_{6} \mathrm{H}_{4} \\
\mathbf{2} \mathbf{R}=4-\mathrm{NO}_{2}-\mathrm{C}_{6} \mathrm{H}_{4} & \mathbf{4} \mathbf{R}=4-\mathrm{F}-\mathrm{C}_{6} \mathrm{H}_{4}
\end{array}
$$

ручи до уваги ці обставини, актуальним є синтез нових речовин як потенційних лікоподібних молекул.

Метою даної роботи став синтез деяких $\mathrm{N}^{3}$ та $\mathrm{C}^{5}$ заміщених похідних 4-імінотіазолідин-2-ону для фармакологічного скринінгу антиоксидантної активності.

Результати й обговорення. Класичним підходом до формування 4-тіазолідонового циклу $є$ реакція [2+3]-циклокоденсації. Отримані
Зазначене перетворення стало можливим за рахунок того, що 3-арил-4-тіоксо-тіазолідин-2они є циклічними тіоамідами, і як наслідок, володіють значною активністю тіонної групи в результаті більшої електрофільності атома Карбону тіокарбонільної групи зазначених сполук порівняно 3 карбонільною у положенні $\mathrm{C}^{4} 3$ арил-тіазолідин-2,4-діонів. Одним 3 доказів будови одержаних сполук $є$ їх кислотний гідроліз до відомих 3-арил-тіазолідин-2,4-діонів:

ISSN 2312-0967. Фармацевтичний часопис. 2015. № 1 
Синтез біологічно активних сполук

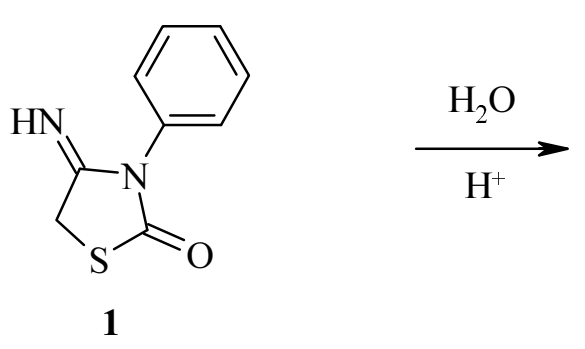

Наявність активної метиленової групи в положенні $\mathrm{C}^{5}$ тіазолідинового циклу 3-феніл-4-іміно-тіазолідин-2-ону дозволяє апробувати ії у реакціях альдольної конденсації з утворенням відповідних 5-ариліденпохідних 3-феніл-4-імінотіазолідин-2-
Synthesis of biologically active compounds<smiles>O=C1CSC(=O)N1c1ccccc1</smiles>

ону. Реакція відбувається у середовищі ацетатної кислоти при взаємодії еквімолярних кількостей 3-феніл-4-імінотіазолідин-2-ону та відповідних ароматичних альдегідів з використанням як каталізатора моноаміноетанолу.<smiles>N=C1CSC(=O)N1c1ccccc1</smiles>

1

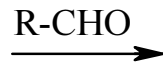

\section{5-10}

$$
\begin{array}{lll}
\mathbf{5} \mathbf{R}=4-\mathrm{F}-\mathrm{C}_{6} \mathrm{H}_{4} & \mathbf{7} \mathbf{R}=4-\mathrm{OCH}_{3}-\mathrm{C}_{6} \mathrm{H}_{4} & \mathbf{9} \mathbf{R}=4-\mathrm{OH}-\mathrm{C}_{6} \mathrm{H}_{4} \\
\mathbf{6 ~ R}=4-\mathrm{Cl}-\mathrm{C}_{6} \mathrm{H}_{4} & \mathbf{8} \mathbf{R}=3,4-\mathrm{OCH}_{3}-\mathrm{C}_{6} \mathrm{H}_{3} & \mathbf{1 0} \mathbf{R}=3-\mathrm{OCH}_{3}-4-\mathrm{OH}-\mathrm{C}_{6} \mathrm{H}_{3}
\end{array}
$$

Наступний етап нашої роботи полягав у подальшій функціоналізації сполуки 1 за положенням $\mathrm{C}^{5}$. Зокрема, досліджувалась реакція нітрозування зазначеного гетероциклу нітритною кислотою. Встановлено, що сполука 1 вступає в<smiles>N=C1CSC(=O)N1c1ccccc1</smiles>

1

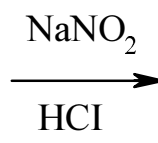

Склад та структура синтезованих сполук підтверджена даними елементного аналізу та ЯМР ${ }^{1} \mathrm{H}$ - спектроскопією.

Антиоксидантну активність сполук досліджували in vitro, визначаючи зменшення концентрації вільного радикала $[17,18]$. Для цього використали відносно стабільний радикал - 2,2-дифеніл-1-пікрилгідразилу (ДФПГ) [19]. Інтенсивно фіолетовий ДФПГ у розчині етанолу характеризується максимумом поглинання світла при 540 нм. У присутності антиоксидантів гаситься вільнорадикальний центр ДФПГ, внаслідок чого розчин поступово втрачає фіолетове забарвлення. Порівняння оптичної густини розчину, реакцію з нітритною кислотою, яка утворюється при взаємодії натрій нітриту з хлоридною кислотою, що призводить до неописанного у хімічній літературі 5-ізонітрозо-4-іміно-3-феніл-тіазолідин-2-ону (11):<smiles>N=C1C(=NO)SC(=O)N1c1ccccc1</smiles>

11

який містить досліджувану субстанцію та надлишок радикала, з оптичною густиною розчину самого радикала дає змогу визначати радикалпоглинальну активність (РПА) сполук (табл. 1).

Як видно 3 результатів таблиці 1, синтезовані сполуки не проявляють високої антиоксидантної активнності, що дозволяє зробити висновок, що функціоналізація 4-імінотіазолідин-2-ону за положеннями $\mathrm{N}^{3}$ та $\mathrm{C}^{5}$ не приводить до появи виразного антиоксидантного ефекту.

\section{Експериментальна частина}

Методи дослідження. Спектри ${ }^{1} \mathrm{H}$ ЯМР синтезованих сполук знімали на приладі «Varian Mercury VX-400», розчинник ДМСО-D, стандарт

ISSN 2312-0967. Pharmaceutical review. 2015. № 1 
<smiles>O=[N+]([O-])c1cc(N(c2ccccc2)c2ccccc2)c([N+](=O)[O-])c([N+](=O)[O-])c1</smiles>

радикал ДФПГ<smiles>O=[N+]([O-])c1cc([N+](=O)[O-])c(NN(c2ccccc2)c2ccccc2)c([N+](=O)[O-])c1</smiles>

відновлений ДФПГ

Таблиця 1. Результати визначення радикал-поглинальної активності

\begin{tabular}{|c|c|c|c|c|c|}
\hline Сполука або стандарт & РПА, \% & Сполука або стандарт & РПА, \% & Сполука або стандарт & РПА, \% \\
\hline Аскорбінова кислота & 24,7 & 4 & 5,2 & 8 & 5,0 \\
\hline 1 & 10,5 & 5 & 3,0 & 9 & 4,0 \\
\hline 2 & 7,4 & 6 & 8,0 & 10 & 6,5 \\
\hline 3 & 5,0 & 7 & 7,6 & 11 & 11,8 \\
\hline
\end{tabular}

- тетраметилсилан. Дані елементного аналізу на вміст Нітрогену і Сульфуру відповідають розрахованим ( $\pm 0,3 \%)$.

Загальна методика синтезу 3-арил-4-іміно-тіазолідин-2-онів (1-4). У колбу вносимо 0,025 моль відповідного 3-арил-4-тіоксо-тіазолідин-2-ону та 25 мл 25 \% водного розчину амоніаку та нагрівають при 80-90 ${ }^{\circ} \mathrm{C}$ протягом 15 хв. Суміш залишаємо до наступного дня. Осад, що випав, відфільтровуємо, промиваємо 50 мл води, невеликою кількістю метанолу і сушать при $60{ }^{\circ} \mathrm{C}$.

Сполука 1. Спектр ЯМР ${ }^{1} \mathrm{H}: 5.83 \mathrm{c}\left(2 \mathrm{H}, \mathrm{CH}_{2}\right), 6.90$ т $\left(1 \mathrm{H}, J=7.3\right.$ Гц, $\left.\mathrm{C}_{6} \mathrm{H}_{5}\right), 7.22$ т $\left(2 \mathrm{H}, J=8.0\right.$ Гц, $\left.\mathrm{C}_{6} \mathrm{H}_{5}\right)$, 7.39 д $\left(2 \mathrm{H}, J=7.7\right.$ Гц, $\left.\mathrm{C}_{6} \mathrm{H}_{5}\right), 8.50$ с $(1 \mathrm{H}, \mathrm{NH})$. Знайдено, \%: N 14.36, S 16.40. $\mathrm{C}_{9} \mathrm{H}_{8} \mathrm{~N}_{2} \mathrm{OS}$. Обчислено, \%: N 14.57, S 16.68. Вихід $58 \%$. Т.пл. $245{ }^{\circ} \mathrm{C}$.

Сполука 2. Спектр ЯМР ${ }^{1} \mathrm{H}: 5.81 \mathrm{c}\left(2 \mathrm{H}, \mathrm{CH}_{2}\right), 7.25$ д $\left(2 \mathrm{H}, J=8.1\right.$ Гц, $\left.\mathrm{C}_{6} \mathrm{H}_{4}\right), 7.48$ д $\left(2 \mathrm{H}, J=7.3\right.$ Гц, $\left.\mathrm{C}_{6} \mathrm{H}_{4}\right)$, 8.53 с $(1 \mathrm{H}, \mathrm{NH})$. Знайдено, \%: N 17.55, S 13.54 . $\mathrm{C}_{9} \mathrm{H}_{7} \mathrm{~N}_{3} \mathrm{O}_{3} \mathrm{~S}$. Обчислено, \%: N 17.71, S 13.52. Вихід 54 \%. Т.пл. 230 ?C.

Сполука 3. Спектр ЯМР ${ }^{1} \mathrm{H}: 5.64$ с $\left(2 \mathrm{H}, \mathrm{CH}_{2}\right), 7.12$ д $\left(2 \mathrm{H}, J=7.9\right.$ Гц, $\left.\mathrm{C}_{6} \mathrm{H}_{4}\right), 7.38$ д $\left(2 \mathrm{H}, J=8.1\right.$ Гц, $\left.\mathrm{C}_{6} \mathrm{H}_{4}\right)$, 8.51 с (1H, NH). Знайдено, \%: N 12.47, S 14.18 . $\mathrm{C}_{9} \mathrm{H}_{7} \mathrm{CIN}_{2} \mathrm{OS}$. Обчислено, \%: N 12.36, S 14.14. Вихід 40 \%. Т.пл. $197^{\circ} \mathrm{C}$.

Сполука 4. Спектр ЯМР ${ }^{1} \mathrm{H}: 5.75$ с (2H, $\left.\mathrm{CH}_{2}\right), 7.21$ д $\left(2 \mathrm{H}, J=7.7\right.$ Гц, $\left.\mathrm{C}_{6} \mathrm{H}_{4}\right), 7.46$ д $\left(2 \mathrm{H}, J=8.4\right.$ Гц, $\left.\mathrm{C}_{6} \mathrm{H}_{4}\right)$, 8.48 с $(1 \mathrm{H}, \mathrm{NH})$. Знайдено, \%: N 13.15, S 15.15. $\mathrm{C}_{9} \mathrm{H}_{7} \mathrm{FN}_{2} \mathrm{OS}$. Обчислено, \%: N 13.33, S 15.25. Вихід $45 \%$. Т.пл. $224^{\circ} \mathrm{C}$.

Загальна методика синтезу 5-ариліденпохідних 3-феніл-4-імінотіазолідин-2-ону (5-10). До 15 мл ацетатної кислоти вносять 0,005 моль сполуки 1,
0,005 моль відповідного ароматичного альдегіду та декілька крапель моноаміноетанолу. Суміш кип'ятять упродовж 30 хв. Кристалічний осад, що випав після охолодження, відфільтровують, промивають водою та висушують. Одержані сполуки перекристалізовують з ацетатної кислоти.

Сполука 5. Спектр ЯМР ${ }^{1} \mathrm{H}: 6.93$ т $(1 \mathrm{H}, J=7.3$ Гц, $\left.\mathrm{C}_{6} \mathrm{H}_{5}\right), 7.28$ т $\left(2 \mathrm{H}, J=8.0\right.$ Гц, $\left.\mathrm{C}_{6} \mathrm{H}_{5}\right), 7.44$ д $(2 \mathrm{H}, J$ $=7.7$ Гц, $\left.\mathrm{C}_{6} \mathrm{H}_{5}\right), 7.42 \mathrm{~T}, 7.64 \mathrm{M}\left(4 \mathrm{H}, 4-\mathrm{F}-\underline{\mathrm{C}}_{6} \underline{\mathrm{H}}_{4}\right), 7.84 \mathrm{C}$ $(1 \mathrm{H}, \mathrm{CH}), 8.54$ с (1H, NH). Знайдено, \%: N 9.33, S 10.90. $\mathrm{C}_{16} \mathrm{H}_{11} \mathrm{FN}_{2} \mathrm{OS}$. Обчислено, \%: N 9.39, S 10.75. Вихід 70 \%. Т.пл. $260-262{ }^{\circ} \mathrm{C}$.

Сполука 6. Спектр ЯМР ${ }^{1} \mathrm{H}: 6.89$ т $(1 \mathrm{H}, J=7.3$ Гц, $\left.\mathrm{C}_{6} \mathrm{H}_{5}\right), 7.22$ т $\left(2 \mathrm{H}, J=8.0\right.$ Гц, $\left.\mathrm{C}_{6} \mathrm{H}_{5}\right), 7.36$ д $(2 \mathrm{H}, J$ $=7.7$ Гц, $\left.\mathrm{C}_{6} \mathrm{H}_{5}\right), 7.45$ д, 7.54 д $(4 \mathrm{H}, J=8.5$ Гц, 4-Cl$\left.\underline{\mathrm{C}}_{6} \underline{\mathrm{H}}_{4}\right) ; 7.83 \mathrm{c}(1 \mathrm{H}, \mathrm{CH}), 8.57 \mathrm{c}(1 \mathrm{H}, \mathrm{NH})$. Знайдено, \%: N 8.85, S 10.10. $\mathrm{C}_{16} \mathrm{H}_{11} \mathrm{CIN}_{2} \mathrm{OS}$. Обчислено, \%: N 8.90, S 10.19. Вихід $61 \%$. Т.пл. 253-254 ${ }^{\circ} \mathrm{C}$.

Сполука 7. Спектр ЯМР ${ }^{1} \mathrm{H}: 3.79$ с $\left(3 \mathrm{H}, \mathrm{CH}_{3} \mathrm{O}\right)$, 6.91 т $\left(1 \mathrm{H}, J=7.3\right.$ Гц, $\left.\mathrm{C}_{6} \mathrm{H}_{5}\right), 7.15$ д $(2 \mathrm{H}, J=8.8$ Гц, 4-MeO- $\left.\underline{\mathrm{C}}_{6} \underline{\mathrm{H}}_{4}\right) ; 7.31$ т $\left(2 \mathrm{H}, J=8.0\right.$ Гц, $\left.\mathrm{C}_{6} \mathrm{H}_{5}\right), 7.47$ д $\left(2 \mathrm{H}, J=7.7\right.$ Гц, $\left.\mathrm{C}_{6} \mathrm{H}_{5}\right), 7.55$ д $(2 \mathrm{H}, J=8.8$ Гц,4-MeO$\left.\underline{\mathrm{C}}_{6} \mathrm{H}_{4}\right) ; 7.79(1 \mathrm{H}, \mathrm{CH}), 8.55 \mathrm{c}(1 \mathrm{H}, \mathrm{NH})$. Знайдено, \%: N 9.15, S 10.40. $\mathrm{C}_{17} \mathrm{H}_{14} \mathrm{~N}_{2} \mathrm{O}_{2} \mathrm{~S}$. Обчислено, \%: N 9.03, S 10.33. Вихід $65 \%$. Т.пл. $248{ }^{\circ} \mathrm{C}$.

Сполука 8. Спектр ЯМР ${ }^{1} \mathrm{H}: 3.77 \mathrm{c}\left(3 \mathrm{H}, \mathrm{CH}_{3} \mathrm{O}\right)$, $3.81 \mathrm{c}\left(3 \mathrm{H}, \mathrm{CH}_{3} \mathrm{O}\right), 6.95 \mathrm{~T}\left(1 \mathrm{H}, J=7.3\right.$ Гц, $\left.\mathrm{C}_{6} \mathrm{H}_{5}\right), 7.04$ c, 7.09 c $\left(3 \mathrm{H}, 3,4-(\mathrm{MeO})_{2}-\underline{\mathrm{C}}_{6} \underline{\mathrm{H}}_{3}\right), 7.26 \mathrm{~T}(2 \mathrm{H}, \mathrm{J}=8.1$ Гц, $\left.\mathrm{C}_{6} \mathrm{H}_{5}\right), 7.42$ д $\left(2 \mathrm{H}, J=7.6\right.$ Гц, $\left.\mathrm{C}_{6} \mathrm{H}_{5}\right), 7.77 \mathrm{c}(1 \mathrm{H}$, $\mathrm{CH}), 8.51$ с (1H, NH). Знайдено, \%: N 8.16, S 9.34. $\mathrm{C}_{18} \mathrm{H}_{16} \mathrm{~N}_{2} \mathrm{O}_{3} \mathrm{~S}$. Обчислено, \%: N 8.23, S 9.42. Вихід 55 \%. Т.пл. $240-242{ }^{\circ} \mathrm{C}$.

Сполука 9. Спектр ЯМР ${ }^{1} \mathrm{H}: 6.89$ д $(2 \mathrm{H}, J=8.0$ Гц, $\left.4-\mathrm{OH}-\underline{\mathrm{C}}_{\underline{6}} \underline{\mathrm{H}}_{4}\right), 6.95$ т $\left(1 \mathrm{H}, J=7.3\right.$ Гц, $\left.\mathrm{C}_{6} \mathrm{H}_{5}\right), 7.22$ т $(2 \mathrm{H}$,

ISSN 2312-0967. Фармацевтичний часопис. 2015. № 1 
$J=8.1$ Гц, $\left.\mathrm{C}_{6} \mathrm{H}_{5}\right), 7.37$ д $\left(2 \mathrm{H}, J=7.6\right.$ Гц, $\left.\mathrm{C}_{6} \mathrm{H}_{5}\right), 7.44$ д $\left(2 \mathrm{H}, J=8.0\right.$ Гц , 4-OH- $\left.\underline{\mathrm{C}}_{6} \mathrm{H}_{4}\right), 7.77 \mathrm{c}(1 \mathrm{H}, \mathrm{CH}), 8.54 \mathrm{c}$ $(1 \mathrm{H}, \mathrm{NH}), 10.25(1 \mathrm{H}, \mathrm{OH})$. Знайдено, \%: N 9.33, S 10.69. $\mathrm{C}_{16} \mathrm{H}_{12} \mathrm{~N}_{2} \mathrm{O}_{2} \mathrm{~S}$. Обчислено, \%: N 9.45, S 10.82. Вихід $52 \%$. Т.пл. $220{ }^{\circ} \mathrm{C}$.

Сполука 10. Спектр ЯМР ${ }^{1} \mathrm{H}: 3.81 \mathrm{c}\left(3 \mathrm{H}, \mathrm{CH}_{3} \mathrm{O}\right)$, 6.93 т $\left(1 \mathrm{H}, J=7.3\right.$ Гц, $\left.\mathrm{C}_{6} \mathrm{H}_{5}\right), 7.01 \mathrm{c}, 7.05$ д $(3 \mathrm{H}, J=$ 8.0 Гц, 3-MeO-4-OH- $\left.\underline{\mathrm{H}}_{6} \mathrm{H}_{3}\right), 7.20$ т $(2 \mathrm{H}, J=8.1$ Гц, $\left.\mathrm{C}_{6} \mathrm{H}_{5}\right), 7.35$ д $\left(2 \mathrm{H}, J=7.6\right.$ Гц, $\left.\mathrm{C}_{6} \mathrm{H}_{5}\right), 7.79$ с $(1 \mathrm{H}, \mathrm{CH})$, 8.52 c (1H, NH), $9.91(1 \mathrm{H}, \mathrm{OH})$. Знайдено, \%: N 8.49, S 9.74. $\mathrm{C}_{17} \mathrm{H}_{14} \mathrm{~N}_{2} \mathrm{O}_{3} \mathrm{~S}$. Обчислено, \%: N 8.58, S 9.82. Вихід 57 \%. Т.пл. 235-236 ${ }^{\circ} \mathrm{C}$.

Сполука 11. 0,05 моль сполуки 1 вносять у 50 мл $15 \% \mathrm{HCl}$, охолоджують до $0^{\circ} \mathrm{C}$ і до суспензії краплями при помішуванні і охолодженні протягом 1 год додають розчин 10,5 г натрій нітриту у 25 мл води. Суміш залишають за кімнатної температури на 12 год. Осад відфільтровують, промивають водою, ацетоном і сушать при $60^{\circ} \mathrm{C}$. Спектр ЯМР ${ }^{1} \mathrm{H}: 6.89$ т $\left(1 \mathrm{H}, J=7.3\right.$ Гц, $\left.\mathrm{C}_{6} \mathrm{H}_{5}\right), 7.19$ т $\left(2 \mathrm{H}, J=8.0\right.$ Гц, $\left.\mathrm{C}_{6} \mathrm{H}_{5}\right), 7.39$ д $\left(2 \mathrm{H}, J=7.7\right.$ Гц, $\left.\mathrm{C}_{6} \mathrm{H}_{5}\right)$, 8.50 с $(1 \mathrm{H}, \mathrm{NH}), 10.05(1 \mathrm{H}, \mathrm{OH})$. Знайдено, \%: $\mathrm{N} 18.90 \mathrm{~S}$ 14.37. $\mathrm{C}_{9} \mathrm{H}_{7} \mathrm{~N}_{3} \mathrm{O}_{2} \mathrm{~S}$. Обчислено, \%: N 18.99, S 14.49. Вихід 65 \%. Т.пл. $182^{\circ} \mathrm{C}$.

Вивчення антиоксидантної активності сполук. Розчини сполук в етанолі (0,3 мл, 20 нмоль/л) додавали до спиртового розчину ДФПГ (2,7 мл,
$150 \mu$ моль/л). Суміш інтенсивно перемішували і залишали на 2 год. Після цього розчин вносили в кювету спектрофотометра і визначали його оптичну густину. Радикал-поглинальну активність сполук обчислювали за формулою:

$$
\text { РПА }=\frac{\mathrm{A}_{\text {ДФПГ }}-\mathrm{A}_{\mathrm{s}}}{\mathrm{A}_{\text {ДФПГ }}} \cdot 100 \%,
$$

де АДФПГ - оптична густина розчину вільного радикала ДФПГ (135 цмоль/л), AS - оптична густина розчину ДФПГ із тестованою речовиною. Як стандарт використовували аскорбінову кислоту (РПА=24,7 \%). Вимірювання проводили тричі з незалежними аліквотами. Відносні відхилення не перебільшували $7 \%$.

Висновки. 1. Здійсненно синтез нових $\mathrm{N}^{3}$ та $\mathrm{C}^{5}$ заміщених похідних 4-іміно-тіазолідин-2-ону шляхом реакцій [2+3]-циклокоденсація, тіонування, амінолізу, альдольної конденсації та нітрозування.

2. Проведено in vitro скринінг антиоксидантної активності синтезованих сполук, результати якого свідчать про те, що серед тестованих речовин не виявлено таких, які б перевищували стандарт.

\section{Література}

1. Зіменковський Б. С. 4-Тіазолідони. Хімія, фізіологічна дія, перспективи: монографія / Б. С. Зіменковський, Р. Б. Лесик. - Вінниця : Нова книга, 2004. - 106 с. 2. Ates O. Synthesis and antimicrobial activity of 4carbethoxymethyl-2-[(б-haloacyl)amino] thiazoles and 5nonsubstituted/substituted 2-[(4-carbethoxymethylthiazol-2yl)imino]-4-thiazolidinones / O. Ates, H. Altintas, G. Otukb // Arzneimittel-Forschung. - 2000. - Vol. 6. - P. 569-575.

3. Thiazolinone analogues of indomycin with antiviral and antibacterial activity / M. R. Harnden, S. Bailey, M.R. Boyd [et al.] // Journal of Medicinal Chemistry. - 1978. - Vol. 1. - P. 82-87.

4. Rout M. K. 2-B-nafthylamino-4-thiazolidone and its derivatives / M. K. Rout, G. N. Mahapatra // Journal of the American Chemical Society. - 1955. - Vol. 5. - P. 24272428.

5. Nasr M. N. Novel 3,3a,4,5,6,7-hexahydroindazole and arylthiazolylpyrazoline derivatives as anti-inflammatory agents / M. N. Nasr, S. A. Said // Archiv. der Pharmazie. 2003. - Vol. 12. - P. 551-519.

6. Janush J. M. New cyclooxygenase-2/5-lipoxygenase inhibitors. 3. 7-tert-butyl-2, 3-dihydro-3,3dimethylbenzofuran derivatives as gastrointestinal safe antiinflammatory and analgesic agents: variations at the 5 position / J. M. Janush, P. A. Young, J. M. Ridgeway // Journal of Medicinal Chemistry. - 1998. - Vol. 18. P. 3515-3529.

7. Martin L. Darbufelone mesilate. Antiarthritic, lipoxygenase

inhibitor, cyclooxygenase-2 inhibitor / L. Martin, X. Rabasseda, J. Castanner // Drugs Future. - 1999. Vol. 8. - P. 853-857.

8. Synthesis, structure-activity relationships, and in vivo evaluations of substituted di-tert-butylphenols as a novel class of potent, selective, and orally active cyclooxygenase2 inhibitors. 1. Thiazolone and oxazolone series. /Y. Song, D. T. Connor, R. Doubleday [et al.] // Journal of Medicinal Chemistry. - 1999. - Vol. 7. - P. 1151-1160.

9. Synthesis and biological evaluation of 5 -[[3,5-bis $(1,1$ dimethylethyl)-4-hydroxyphenyl]methylene]oxazoles, thiazoles, and -imidazoles: novel dual 5-lipoxygenase and cyclooxygenase inhibitors with antiinflammatory activity / P. C. Unangst, D. Connor, W. A. Cetenko [et al.] // Journal of Medicinal Chemistry. - 1994. - Vol. 2. - P. 322-328. 10. Kulkarni S. K. Positioning dual inhibitors in the treatment of pain and infammatory disorders / S. K. Kulkarni, V. P. Singh // Infammopharmacology. 2008. - Vol. 1. - P. 1-15.

11. Discovery of Small Molecule Integrin $a b_{3}$ antagonists as novel anticancer agents / R. Dayam, F. Aiello, J. Deng [et al.] // Journal of Medicinal Chemistry. - 2006. - Vol. 15. - P. 4526-4534.

12. Design, synthesis, cytoselective toxicity, structureactivity relationships, and pharmacophore of thiazolidinone derivatives targeting drug-resistant lung cancer cells / H. Zhou, S. Wu, S. Zhai [et al.] // Journal of Medicinal Chemistry. - 2008. - Vol. 5. - P. 1242-1251.

ISSN 2312-0967. Pharmaceutical review. 2015. № 1 
13. Synthesis of 5-arylidene-2-amino-4-azolones and evaluation of their anticancer activity / I. Subtelna, D. Atamanyuk, E. Szymanska, [et al.] // Bioorg. Med. Chem. -2010. - Vol. 18(14). - P. 5089-5101.

14. Antidiabetic and adipogenic properties in a newly synthesized thiazolidine derivative, FPFS-410 / N. Norisada, H. Masuzaki, M. Fujimoto [et al.] // Metabolism. - 2004. Vol. 12. - P. 1532-1537.

15. 2-Heteroarylimino-5-benzylidene-4-thiazolidinones analogues of 2-thiazolylimino-5-benzylidene-4thiazolidinones with antimicrobial activity: Synthesis and structure-activity relationship / P. Vicini, A. Geronikaki, M. Incerti [et al.] // Bioorganic and Medicinal Chemistry. - 2008. - Vol. 7. - P. 3714-3724.
16. Грищук А. П. Синтез и превращения 4-тионтиазолидона-2 / А. П. Грищук, И. Д. Комарица, С. Н. Баранов // Химия гетероциклических соединений. - 1966. - № 5. - C. 706-709.

17. Blois M. S. Antioxidant determinations by the use of a stable free radical / M. S. Blois // Nature. - 1958. Vol. 181. - P. 1199-1200.

18. Molyneux $P$. The use of the stable free radical diphenylpicrylhydrazyl (DPPH) for estimating antioxidant activity / P. Molyneux // J. Sci. Technol. - 2004. - Vol. 26. - P. 211-219.

19. Stable Radicals. Fundamentals and Applied Aspects of Odd-Electron Compounds / Edited by Robin G. Hicks. John Wiley \& Sons. - Chichester, 2010. - 606 p.

\section{СИНТЕЗ И ИССЛЕДОВАНИЕ АНТИОКСИДАНТНОЙ АКТИВНОСТИ НЕКОТОРЫХ ПРОИЗВОДНЫХ НА ОСНОВЕ 4-ИМИНОТИАЗОЛИДИН-2-ОНА}

\section{Т. И. Чабан}

Львовский национальный медицинский университет имени Даниила Галицкого

Резюме: на основе реакций [2+3]-циклокоденсации, тионирования и аминолиза осуществлен синтез новых $\mathrm{N}^{3}$ замещенных производных 4-имино-тиазолидин-2-она. Для 3-фенил-4-имино-тиазолидин-2-она проведена функционализация за положением $\mathrm{C}^{5}$ в реакциях альдольной конденсации и нитрозирования. Скрининговые исследования антиоксидантной активности проводились in vitro, определяя уменьшения концентрации свободного радикала. Среди тестируемых веществ обнаружены соединения только с умеренной активностью.

Ключевые слова: [2 +3]-циклокоденсация, 3-арил-4-имино-тиазолидин-2-оны, альдольная конденсация, нитрозирование, антиоксидантная активность.

\section{SYNTHESIS AND ANTIOXIDANT ACTIVITY EVALUATION OF SOME NOVEL DERIVATIVES BASED ON 4-IMINOTHIAZOLYDINE-2-ONE}

\section{T. I. Chaban}

\section{Lviv National Medical University by Danylo Halytsky}

Summary: novel $\mathrm{N}^{3}$ substituted derivatives of 4-imino-thiazolydine-2-one were synthesized under the reactions of $[2+3]$ cyclocondensation, thionation and ammonolysis. The functionalization of 3-phenyl-4-imino-thiazolydine-2-one was carried out in its $\mathrm{C}^{5}$ position under aldol condencation and nitrosylation reactions. The antioxidant activity pharmacological screening of the synthesized compounds was performed in vitro by the method of scavenging effect on free radicals. The compounds with the moderate activity only were found out among the tested ones.

Key words: [2+3] cyclocondensation, 3-aryl-4-imino-thiazolydine-2-ones, aldol condensation, nitrosylation, antioxidant activity. 